(C) 2004 Australian Council for Educational Research. This article may not exactly replicate the final version published in Australian Journal of Career Development. It is not a copy of the record. Final and authorised version first published in Australian Journal of Career Development in Vol 13, Issue 1, published by the Australian Council for Educational Research.

Patton, Wendy and Watson, Mark B and Creed, Peter A (2004) Career Maturity Of Australian And South African High School Students: Developmental And Contextual Explanations. Australian Journal of Career Development 13(1):33-41.

\title{
C AREER MATURITY OF AUSTRALIAN AND SOUTH AFRICAN HIGH SCHOOL STUDENTS: DEVELOPMENTAL AND CONTEXTUAL EXPLANATIONS
}

\author{
WENDY PATTON \\ Queensland University of Technology \\ MARK B . WATSON \\ University of Port Elizabeth \\ PETER A. CREED \\ Griffith University
}

The present study investigates the career maturity of 1090 high school students in Years 8 to 12 in Australia $(n=656)$ and South Africa $(n=434)$. Scores on the Australian version of the Career Development Inventory were analysed. While a developmental explanation for career maturity was supported, gender differences between countries and differences at school transition points were found. The relevance of school career education programs to prepare students for career decisions is discussed.

The career maturity construct is central to the developmental approach (Super, 1957, 1990) to understanding career behaviour. It refers, broadly, to the individual's readiness to make informed, age- appropriate career decisions and cope with career development tasks (Savickas, 1984). Crites' (1971) model of career maturity proposed that it consists of affective and cognitive dimensions. The cognitive dimension is composed of decisionmaking skills, while the affective dimension includes attitudes toward the career decisionmaking process.

Theoretical assumptions would suggest a strong relationship between age and career maturity, however, research findings have been varied. A number of researchers have found such relationships (Herr \& Enderlein, 1976; Neice \& Bradley, 1979; Post-Kammer, 1987; Thompson \& Lindeman, 1981; Wallace-Broscious, Serafica \& Osipow, 1994). This developmental increase across age has also been reported with non-American samples, for example in Israel (Fouad, 1988), Australia (Lokan, 1984; Patton \& Creed, in press), Canada (Alvi \& Khan, 1983), South Africa (Watson \& van Aarde, 1986), Nigeria (Achebe, 1982), and Lebanon (Moracco, 1976).

Several researchers have commented that career maturity may be more usefully differentiated by year of schooling rather than age, due to the influence of the educational milieu as the primary agent of career development behaviour and the year-related career decisions students are required to make (Watson \& Van Aarde, 1986). More recently, however, Powell and Luzzo (1998) demonstrated that neither age nor year was related to 
(C) 2004 Australian Council for Educational Research. This article may not exactly replicate the final version published in Australian Journal of Career Development. It is not a copy of the record. Final and authorised version first published in Australian Journal of Career Development in Vol 13, Issue 1, published by the Australian Council for Educational Research.

career maturity.

Research exploring the impact of gender on career maturity is also far from equivocal. The great majority of studies has found that females of a number of age groups have higher scores on career maturity measures than males (Alvi \& Khan, 1983; Herr \& Enderlein, 1976; King, 1989; Lokan, 1984; Luzzo, 1995; Westbrook, 1984). In other studies (Fouad, 1988), females were higher on some subscales only. However, Achebe's (1982) study in Nigeria reported males scoring higher than females. Notably, however, South African research has failed to find gender differences in the career maturity of high school students (Watson \& van Aarde, 1986).

The career maturity construct is undergoing a renewal of interest (Patton \& Lokan, 2001); in particular researchers are questioning its broad applicability. In criticising the construct's focus on the individual, its ties to developmental stage models, and its lack of inclusion of contexts of time and culture, Vondracek and Reitzle (1998) suggest the assumption of identifiable age-related maturational regularities in career maturity might be affected by other variables such as historical time, cultural and economic context, and the individualisation of educational pathways. However, despite this theoretical critique, and a more far reaching theoretical debate (Savickas, 1994), Vondracek and Reitzle emphasise the practical utility of career maturity data, particularly for work with adolescents, a view echoed by Raskin (1998). In addition, Ohler and Levinson (1994) emphasise the relevance of assessing career maturity in preparation for developing counselling and education programs for adolescents.

\section{INTRODUCING CONTEXT}

Very little work has been conducted outside the United States in exploring the relevance of career maturity. Notable exceptions include studies conducted in Nigeria (Achebe, 1982), Israel (Fouad, 1988), Lebanon (Moracco, 1976), India (Gupta, 1987), Canada (Alvi \& Khan, 1983; Lokan, Boss, \& Patsula, 1982), and more recently, Australia (Patton \& Creed, 2001). Even fewer are comparison studies across cultures. A considerable body of work has emanated from South Africa, which has consistently shown that black high school (Hickson \& White, 1989; Watson \& Van Aarde, 1986) and first year university (Reid-Van Niekerk \& Van Niekerk, 1990; Watson, Stead, \& De Jager, 1995) students are less career mature than their white counterparts.

What is being explored further is the nature of the applicability of the career maturity construct to populations other than the sample of origin: a homogeneous group of white, middle-class, American adolescent males experiencing continuous vocational development during a time of full employment during the 1950s. Research by Schmitt-Rodermund and Silbereisen (1998) has demonstrated that career maturation is influenced by differences in social and political systems, reflecting the relevance of the developmental contextual theoretical model of Vondracek, Lerner and Schulenberg (1986). In this regard, Stead and Watson (1998) have also suggested that, due to the unique features of South African society, the career maturity construct may be inappropriate.

In a time of global change in the world of work and in understandings and constructions of career, related changes are occurring in the youth labour market and in adolescent educational and career pathways. Given the key role of the career maturity construct in career development, research needs to clarify the place of context within career behaviour. The present study sought to contribute to this understanding through an examination of 
(C) 2004 Australian Council for Educational Research. This article may not exactly replicate the final version published in Australian Journal of Career Development. It is not a copy of the record. Final and authorised version first published in Australian Journal of Career Development in Vol 13, Issue 1, published by the Australian Council for Educational Research.

career maturity in a group of adolescents from similar socioeconomic backgrounds in two countries. Prior to describing the study, key features of the educational and youth labour market context in each country will be examined.

\section{AUSTRALIA AND SOUTH AFRICA}

Both countries are witnessing significant changes within the educational context and the youth labour market. In Australia, despite a sharp rise during the 1980s which peaked at 77 per cent in 1992, retention of students into post-compulsory schooling has fallen to 71 per cent in 1996 (Sweet, 1998). Similarly, in South Africa, there is a 60 per cent attrition rate between the end of primary and the end of senior high school (Statistics South Africa, 2000). Only 45 per cent of South African youth attained a Year 12 pass in 1998, down from 57 per cent in 1994. Such a trend is of particular concern as it has occurred in a context of declining full-time employment opportunities and increasing evidence about the disadvantages of early school leaving.

In addition to high youth unemployment, data indicate that worldwide most work for young people is short term and part-time. In Australia, the proportion of 15 to 19 year olds with a full-time job fell from 32 per cent in the mid-1980s to 17 per cent by August 1996. In addition, almost 15 per cent of 15 to 19 year olds are neither in full-time work nor full-time education (Sweet, 1998).

Further, where previously there were a small number of relatively clearly defined trade and professional pathways, there are now a large number of skill areas with multiple entry points. As such, there is an increasing demand for advice in the broad array of training opportunities and job pathways available. Such a demand places new pressures for provision of career development services in schools and in the post-compulsory education and training sector (MCEETYA, 2000). However, in both countries, while many policy reports emphasise the need for a comprehensive career education program as a part of the core secondary school curriculum, there has been a decline in real support for career education in Australia (Patton, 2000), and in South Africa (Akhurst \& Mkhize, 1999).

In exploring context, it is also relevant to highlight the different school transition points in the two countries. Although Herr and Enderlein (1976) noted the relevance of curriculum and school on the level of career maturity of adolescents, very little work has attempted to explore this issue further. Students in Australia choose subjects which are crucial in eventual post-school options in Year 10; in South Africa this decision is made in Year 9.

\section{THE PRESENT STUDY}

The present study chose one school in each country, matched as closely as possible for socioeconomic status (SES). This variable has been hypothesised to be related to career maturity (Super, 1990), although most studies have found only a minor or no correlation between career maturity (CM) and SES in school age adolescents (Crites, 1978; Jordaan \& Heyde, 1979; Super \& Nevill, 1984). SES was controlled for in the present study through careful selection of schools which were predominantly white and middle class. It was hypothesised that, although a developmental pattern would be evident across both schools, the influence of transition points in each school would be evident. It was also hypothesised that gender differences would be evident, with females scoring higher on 
(C) 2004 Australian Council for Educational Research. This article may not exactly replicate the final version published in Australian Journal of Career Development. It is not a copy of the record. Final and authorised version first published in Australian Journal of Career Development in Vol 13, Issue 1, published by the Australian Council for Educational Research.

career maturity than males.

\section{METHOD}

\section{Participants}

The total number of participants included in the study was 1090 secondary school students enrolled in Years 8-12 across two high schools, one in the south-eastern part of Australia and the other in South Africa. There were 656 (60 per cent) students from Australia, made up of 353 (54 per cent) females and 303 (46 per cent) males. These Australian students had a mean age of 15.07 years $(S D=1.51)$. There were 434 (40 per cent)students from South Africa, made up of 232 (54 per cent) females and 202 (46 per cent) males. The South African students had a mean age of 15.30 years ( $\mathrm{SD}=1.39$ ). The two schools were selected as they were considered to be matched on socioeconomic and geographic grounds. Both schools were suburban-based in medium sized cities, and each was established as middle level socioeconomic status due to location within the respective cities.

\section{Instrument}

The Australian version of the Career Development Inventory (CDI-A; Lokan, 1984) was used to measure career maturity. The CDI-A has 72 items and is designed for students in Years 8-12. It measures several aspects of career development, including career planning orientation, awareness and use of resources, knowledge of the career development process, knowledge of the world of work, and knowledge and use of decision-making principles. Four subscales, two composite scales and a total scale score can be calculated for the CDI-A. The four subscales are reported in this study. These are Career Planning (20 items), Career Exploration (16 items), World of Work Knowledge (24 items), and Career Decision Making (12 items). Sound psychometric properties have been reported (Lokan, 1984), which are similar to those reported for the American version of the inventory (Pinkney \& Bozik, 1994). Internal reliability coefficients calculated in the present study for the subscales were $0.93,0.76,0.80$ and 0.70 respectively.

\section{Procedure}

Schools were selected in both countries to match participants as closely as possible. Survey forms containing the CDI-A and asking questions about age, grade and gender were administered to students in Years 8-12 across the two secondary schools that participated in the study. The classroom teachers, who had been provided with instructions regarding the administration protocol, administered the survey forms.

\section{RESULTS}

A MANOVA was used to assess the effects of Gender, Grade and School on the Career Development Inventory subscales. All multivariate main effects were significant $(p<$ 0.001 ), as were the multivariate interaction effects for School by Year and School by Gender $(p<0.001)$. At the univariate level, significant main effects for Gender were found for World of Work Knowledge, $F(1,1070)=24.73, p<0.001$, and Career Decision Making, $F(1,1070)=7.20, p<0.01$. 
(C) 2004 Australian Council for Educational Research. This article may not exactly replicate the final version published in Australian Journal of Career Development. It is not a copy of the record. Final and authorised version first published in Australian Journal of Career Development in Vol 13, Issue 1, published by the Australian Council for Educational Research.

Significant main effects for Grade were found for Career Planning, $F(4,1070)=19.67, p$ $<0.001$, Career Exploration, $F(4,1070)=20.44, p<0.001$, World of Work Knowledge, $F(4,1070)=22.19, p<0.001$, and Career Decision Making, $F(4,1070)=17.44, p<$ 0.001. One significant main effect for School was found for Career Decision Making, $F(1,1070)=15.79, p<0.001$. Significant interaction effects for School by Grade were found for Career Planning, $F(4,1070)=6.03, p<0.001$, Career Exploration, $F(4,1070)=3.79, p<$ 0.01 , and Career Decision Making, $F(4,1070)=4.70, p<0.01$. Significant interaction effects for School by Gender were found for Career Exploration, $F(1,1070)=5.81, p<.05$, World of Work Knowledge, $F(1,1070)=41.71, p<0.001$, and Career Decision Making, $F(1,1070)=81.66, p<$ 0.001 . Summary data are reported in Tables 1 and 2.

For the Australian school, females scored lower than males at Year 8 for Career Planning, higher than males overall and at Year 10 for Career Exploration, higher than males overall and at each Year for World of Work Knowledge and Career Decision Making. For the South African school, no gender differences were identified for Career Planning or Career Exploration, while females scored lower than males overall and at Years 9 and 10 for World of Work Knowledge, and lower than males overall and at Years 9-11 for Career Decision Making. See Table 1 for t-values and levels of significance.

There were no differences between Australian females and South African females on Career Exploration. Australian females scored lower than South African females at Year 9 for Career Planning, higher than South African females overall and at all years for World of Work Knowledge, and higher than South African females overall and at Year 8 for Career Decision Making. Australian males scored higher than South African males at Year 8 and lower than South African males at Year 9 and 12 for Career Planning, lower than South African males overall and at Year 9 for Career Exploration, lower than South African males overall and at Years 9-10 and 12 for World of Work Knowledge, and lower than South African males overall and at Years 9-12. See Table 1 for t-values and levels of significance.

Australian students (males and females combined) scored lower than the South African students at Years 9 and 12 for Career Planning, lower than the South African students at Years 9 for Career Exploration, and lower than the South African students overall and at Years 9 and 10 for Decision Making. There were no differences at for World of Work Knowledge. See Table 2 for t-values and levels of significance.

In relation to differences across Years for Australian (males, females and total) and South African (males, females and total) students, where significant differences were found on the post hoc ANOVAs, students in the higher grades reported higher scores in almost all instances. The one exception was that Year 8 Australian students (males, and males and females combined) scored higher on Career Planning than those in Year 9. These differences are indicated in Tables 1 and 2. 
(C) 2004 Australian Council for Educational Research. This article may not exactly replicate the final version published in Australian Journal of Career Development. It is not a copy of the record. Final and authorised version first published in Australian Journal of Career Development in Vol 13, Issue 1, published by the Australian Council for Educational Resear@ 2004 Australian Council for Educational Research. This article may not exactly replicate the final version published in Australian Journal of

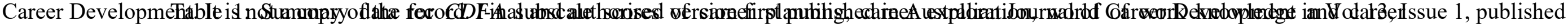

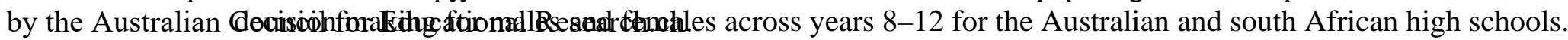

\begin{tabular}{|c|c|c|c|c|c|c|c|c|c|c|c|c|c|c|c|c|}
\hline \multirow[b]{3}{*}{ Year } & \multicolumn{6}{|c|}{ Australian High School } & \multicolumn{10}{|c|}{ South African High School } \\
\hline & \multicolumn{3}{|c|}{ Males } & \multicolumn{3}{|c|}{ Females } & \multirow[b]{2}{*}{$t^{i}$} & \multicolumn{3}{|c|}{ Males } & \multicolumn{3}{|c|}{ Females } & \multirow[b]{2}{*}{$t^{2}$} & \multirow[b]{2}{*}{$t^{3}$} & \multirow[b]{2}{*}{$t^{4}$} \\
\hline & $N$ & $M$ & $S D$ & $N$ & $M$ & SD & & $N$ & $M$ & SD & $N$ & $M$ & $S D$ & & & \\
\hline \multicolumn{17}{|c|}{ CDI-A Career Planning } \\
\hline 8 & 91 & 60.19 & 13.13 & 104 & $56.03_{\mathrm{a}, \mathrm{bc}}$ & 13.82 & $2.15^{*}$ & 44 & $54.70_{a, b}$ & 12.16 & 44 & $56.25 \mathrm{a}$ & 13.18 & -0.57 & $2.33^{*}$ & -0.09 \\
\hline 9 & 35 & $49.89_{a, b c, d}$ & 12.86 & 48 & $54.65_{\text {def }}$ & 12.27 & -1.71 & 49 & $59.43_{c}$ & 11.28 & 49 & 60.59 & 12.65 & -0.48 & $-\left.3.6\right|^{* *}$ & $-2.35^{*}$ \\
\hline 10 & 79 & $65.25_{b}$ & 12.55 & 93 & $64.05_{\mathrm{a}, \mathrm{d}}$ & 11.88 & 0.64 & 69 & 61.54 & 11.45 & 45 & 63.58 & 12.97 & -0.88 & 1.87 & 0.21 \\
\hline 11 & 53 & $58.92_{c}$ & 13.26 & 54 & $62.80_{b, s}$ & 11.43 & -1.62 & 52 & $58.7 I_{d}$ & 11.54 & 45 & 63.40 & 13.17 & -1.87 & 0.09 & -0.24 \\
\hline 12 & 45 & $62.1 \mathrm{I}_{\mathrm{d}}$ & 13.76 & 54 & $65.67_{c f}$ & 10.08 & -1.48 & 18 & $69.56_{b c, d}$ & 9.83 & 19 & 67.68 & 10.40 & 0.56 & $-2.09^{*}$ & -0.74 \\
\hline Total & 303 & 60.38 & 13.72 & 353 & 60.46 & 12.91 & -0.08 & 232 & 59.78 & 11.94 & 202 & 61.60 & 13.10 & -1.51 & 0.53 & -0.10 \\
\hline \multicolumn{17}{|c|}{ CDf-A Career Exploration } \\
\hline 8 & 91 & $34.05_{a}$ & 8.90 & 104 & $33.46_{a, b c}$ & 7.95 & 0.49 & 44 & 34.34 & 9.90 & 44 & 33.05 & 10.12 & 0.61 & -0.17 & 0.24 \\
\hline 9 & 35 & $29.1 I_{b c, d}$ & 9.45 & 48 & $32.19_{\text {deff }}$ & 7.80 & -1.62 & 49 & 36.22 & 7.54 & 49 & 34.80 & 8.51 & 0.88 & $-3.83^{* * *}$ & -1.57 \\
\hline 10 & 79 & $36,27 b$ & 8.47 & 93 & $\left.39.1\right|_{\mathrm{ad}}$ & 6.79 & $-2.44^{*}$ & 69 & 35.71 & 8.68 & 45 & 36.71 & 9.31 & -0.59 & 0.39 & 1.72 \\
\hline 11 & 53 & $35.9 I_{c}$ & 9.66 & 54 & $39.06_{b e}$ & 6.88 & -1.95 & 52 & 38.92 & 9.09 & 45 & 37.84 & 8.79 & 0.59 & -1.65 & 0.77 \\
\hline 12 & 45 & $38.78_{\mathrm{ad}}$ & 9.82 & 54 & $40.57_{c f}$ & 7.49 & -1.03 & 18 & 40.78 & 7.49 & 19 & 39.95 & 9.69 & 0.29 & -0.78 & 0.29 \\
\hline Total & 303 & 35.09 & 9.45 & 353 & 36.72 & 8.05 & $-2.36^{*}$ & 232 & 36.67 & 8.86 & 202 & 36.00 & 9.39 & 0.76 & $-1.98^{*}$ & 0.95 \\
\hline \multicolumn{17}{|c|}{ CDI-A World of Work Knowledge } \\
\hline 8 & 91 & $12.70_{a}$ & 4.98 & 104 & $14.76_{a, b}$ & 4.43 & $-3.03^{* *}$ & 44 & $13.30_{\mathrm{a}, \mathrm{b}, \mathrm{d}, \mathrm{d}}$ & 3.48 & 44 & $13.2 \mathrm{O}_{\mathrm{a}, \mathrm{b}}$ & 2.87 & 0.13 & -0.80 & $2.54^{*}$ \\
\hline 9 & 35 & $11.69_{b}$ & 5.43 & 48 & $15.33_{c, d}$ & 4.37 & $-3.42^{* *}$ & 49 & 15.27 & 2.67 & 49 & $13.59_{c, d}$ & 3.09 & $2.87^{* *}$ & $-3.65^{* *}$ & $2.26^{*}$ \\
\hline 10 & 79 & 13.80 & 5.13 & 93 & 16.49 & 5.02 & $-3.48^{* *}$ & 69 & $15.87_{b}$ & 3.17 & 45 & $14.44_{\mathrm{a}, \mathrm{b}, \mathrm{c}}$ & 3.45 & $2.26^{*}$ & $-3.00^{* *}$ & $2.80^{* *}$ \\
\hline 11 & 53 & $15.74_{a, b}$ & 4.84 & 54 & $17.78_{\mathrm{a},}$ & 4.42 & $-2.28^{*}$ & 52 & $15.75_{c}$ & 3.39 & 45 & 16.07 & 3.04 & -0.48 & -0.02 & $2.27^{*}$ \\
\hline 12 & 45 & $15.00_{b}$ & 5.14 & 54 & $18.50_{b, d}$ & 4.13 & $-3.68^{* * *}$ & 18 & $17.56_{d}$ & 2.31 & 19 & 16.26 & 2.51 & 1.63 & $-2.72^{* *}$ & $2.22^{*}$ \\
\hline Total & 303 & 13.74 & 5.20 & 353 & 16.33 & 4.72 & $-6.63^{* * *}$ & 232 & 15.36 & 3.31 & 202 & 14.50 & 3.26 & $\left.2.7\right|^{* *}$ & $-4.38^{* * *}$ & $5.37^{* * *}$ \\
\hline \multicolumn{17}{|c|}{ CDI-A Career Decision Making } \\
\hline 8 & 91 & 5.31 & 2.60 & 104 & $6.09_{\mathrm{a}, \mathrm{b}}$ & 2.64 & $-2.07^{*}$ & 44 & $5.64_{\mathrm{a}, \mathrm{bx}, \mathrm{d}}$ & 2.16 & 44 & $4.82_{a, b}$ & 2.22 & 1.75 & -0.73 & $2.80^{* *}$ \\
\hline 9 & 35 & $3.86_{\mathrm{a}, \mathrm{b}}$ & 2.26 & 48 & $6.15_{c, d}$ & 3.04 & $-3.93^{* * *}$ & 49 & 7.51 & 2.27 & 49 & $5.6 I_{c}$ & 2.32 & $4.09^{* * *}$ & $-7.27^{* * *}$ & 0.97 \\
\hline 10 & 79 & 4.99 & 2.84 & 93 & $6.40_{e f f}$ & 3.00 & $-3.15^{* *}$ & 69 & $7.7 \mathrm{I}_{6}$ & 2.18 & 45 & 6.04 & 2.08 & $4.06^{* * *}$ & $-6.59^{* * *}$ & 0.81 \\
\hline 11 & 53 & $5.9 \mathrm{I}_{\mathrm{a}}$ & 2.96 & 54 & $8.06_{a c e s}$ & 2.76 & $-3.88^{* * *}$ & 52 & $8.02_{c}$ & 2.35 & 45 & $7.02_{a, c}$ & 2.38 & $2.07^{*}$ & $-4.05^{* * *}$ & 1.97 \\
\hline 12 & 45 & $5.80_{b}$ & 3.44 & 54 & $8.17_{b d f f}$ & 2.72 & $-3.75^{* * *}$ & 18 & $8.1 I_{d}$ & 1.78 & 19 & $6.89_{b}$ & 2.13 & 1.88 & $-3.49^{* *}$ & 1.85 \\
\hline Total & 303 & 5.23 & 2.87 & 353 & 6.80 & 2.94 & $-6.65^{* * *}$ & 232 & 7.38 & 2.35 & 202 & 5.97 & 2.36 & $6.19^{* * *}$ & $-9.47^{* * *}$ & $3.62^{* * *}$ \\
\hline
\end{tabular}

Note 1: $t 1=\mathrm{t}$-values and levels of significance for differences between Australian males and females; $t 2=$ values for differences between South African males and females;

$t 3=$ values for differences between Australian and South African males; $t 4=$ values for differences between Australian and South African females.

Note 2: Means in the same subscale column that share the same subscript differ significantly at $p<.05$ on the Tukey honestly significant difference comparison.

Note $3: * p<.05 ; * * p<.01 ; * * * p<.001$ 
(C) 2004 Australian Council for Educational Research. This article may not exactly replicate the final version published in Australian Journal of Career Development. It is not a copy of the record. Final and authorised version first published in Australian Journal of Career Development in Vol 13, Issue 1, published by the Australian Council for Educational Research.

Table 2: Summary data for $C D I-A$ subscale scores of career planning, career exploration, world of work knowledge and career decision making for total scores for each school for years 8-12

\begin{tabular}{|c|c|c|c|c|c|c|c|}
\hline \multirow[b]{2}{*}{ Year } & \multicolumn{3}{|c|}{ Australian High School } & \multicolumn{4}{|c|}{ South African High School } \\
\hline & $N$ & $M$ & $S D$ & N & M & $S D$ & $t^{1}$ \\
\hline \multicolumn{8}{|c|}{ CDI-A Career Planning } \\
\hline 8 & 195 & $57.97_{\mathrm{abc}}$ & 13.62 & 88 & $55.48_{\mathrm{a}, \mathrm{b}, \mathrm{c}}$ & 12.63 & 1.46 \\
\hline 9 & 83 & $52.64_{\text {a.f. }}$ & 12.67 & 98 & $60.0 I_{d}$ & 11.94 & $-.03^{* * *}$ \\
\hline 10 & 172 & $64.60_{\text {be }}$ & 12.17 & 114 & $62.34_{\mathrm{a}, \mathrm{e}}$ & 12.06 & 1.55 \\
\hline 11 & 107 & $60.88_{f}$ & 12.46 & 97 & $60.89_{b f}$ & 12.48 & -0.01 \\
\hline 12 & 99 & $64.05_{c, g}$ & 11.96 & 37 & $68.59_{\text {c.deff }}$ & 10.03 & $-2.06^{*}$ \\
\hline Total & 656 & 60.43 & 13.28 & 434 & 60.63 & $|2.5|$ & -0.26 \\
\hline \multicolumn{8}{|c|}{ CDI-A Career Exploration } \\
\hline 8 & 195 & $33.74_{\text {abcc }}$ & 8.39 & 88 & $33.69_{a, b}$ & 9.98 & 0.04 \\
\hline 9 & 83 & $30.89_{\text {deff }}$ & 8.62 & 98 & $35.5 I_{c}$ & 8.03 & $-3.73^{* * *}$ \\
\hline 10 & 172 & $37.80_{\mathrm{ad}}$ & 7.72 & 114 & 36.11 & 8.91 & 1.71 \\
\hline 11 & 107 & $37.50_{b, e}$ & 8.48 & 97 & 38.42 & 8.92 & -0.76 \\
\hline 12 & 99 & $39.76_{c f}$ & 8.63 & 37 & $40.35_{b, c}$ & 8.58 & -0.36 \\
\hline Total & 656 & 35.96 & 8.76 & 434 & 36.36 & 9.10 & -0.72 \\
\hline \multicolumn{8}{|c|}{ CDI-A World of Work Knowledge } \\
\hline 8 & 195 & $13.80_{\mathrm{abc}}$ & 4.79 & 88 & $13.25_{\mathrm{abc}}$ & 3.17 & 1.14 \\
\hline 9 & 83 & $13.80_{d e}$ & 5.10 & 98 & $14.43_{\mathrm{d}, \mathrm{e}}$ & 2.99 & -1.00 \\
\hline 10 & 172 & 15.26 & 5.23 & 114 & $|5.3|_{\mathrm{a}}$ & 3.34 & -0.10 \\
\hline 11 & 107 & $16.77_{b, d}$ & 4.72 & 97 & $15.90_{b, d}$ & 3.22 & 1.55 \\
\hline 12 & 99 & $|6.9|_{C B}$ & 4.92 & 37 & $16.89_{C B}$ & 2.47 & 0.03 \\
\hline Total & 656 & 15.13 & 5.11 & 434 & 14.96 & 3.31 & -0.69 \\
\hline \multicolumn{8}{|c|}{ CDI-A Career Decision Making } \\
\hline 8 & 195 & $5.72_{\mathrm{ab}}$ & 2.64 & 88 & $5.23_{\mathrm{a}, \mathrm{bcc} d \mathrm{~d}}$ & 2.22 & 1.64 \\
\hline 9 & 83 & $5.18_{c, d}$ & 2.95 & 98 & $6.56_{\mathrm{a}, \mathrm{e}}$ & 2.47 & $-3.37^{* *}$ \\
\hline 10 & 172 & $5.75_{\text {eff }}$ & 3.00 & 114 & $7.05_{b}$ & 2.28 & $-4.16^{* * *}$ \\
\hline 11 & 107 & $6.99_{\mathrm{acces}}$ & 3.05 & 97 & $7.56_{c s}$ & 2.40 & -1.48 \\
\hline 12 & 99 & $7.09_{b d f}$ & 3.27 & 37 & $7.49_{d}$ & 2.04 & -0.84 \\
\hline Total & 656 & 6.07 & 3.01 & 434 & 6.72 & 2.46 & $-3.88^{* * *}$ \\
\hline
\end{tabular}

Note 1: $t^{1}=\mathrm{t}$-values and levels of significance for differences across the two schools

Note 2: Means in the same subscale column that share the same subscript differ significantly at $p<.05$ on the Tukey honestly significant difference comparison.

Note 3: * $p<.05 ; * * p<.01 ; * * * p<.001$.

\section{Discussion}

The findings of the present study for year illustrate developmental differences in career maturity and generally reflect the developmental assumptions for this construct. In both 
(C) 2004 Australian Council for Educational Research. This article may not exactly replicate the final version published in Australian Journal of Career Development. It is not a copy of the record. Final and authorised version first published in Australian Journal of Career Development in Vol 13, Issue 1, published by the Australian Council for Educational Research.

countries, students in higher school grades scored higher on the four subscales of Career Exploration, Career Planning, World of Work Knowledge, and Career Decision Making than students in lower grades. These data are supportive of findings reporting monotonic progression of career maturity scores in adolescent samples across a number of countries (Achebe, 1982; Alvi \& Khan, 1983; Fouad, 1988; Herr \& Enderlein, 1976; Lokan, 1984; Moracco, 1976; Neice \& Bradley, 1979; Post-Kammer, 1987; Wallace-Broscious et al., 1994; Watson \& van Aarde, 1986), thereby suggesting the broad applicability of the career maturity construct across different national contexts.

In relation to gender, the present data of the South African sample generally support contentions from previous South African research (Watson \& van Aarde, 1986) of no gender differences in high school students, particularly on attitudinal career maturity. A small difference was found in which females were lower than males on the career maturity knowledge subscale at Years 9 and 10. However, in the Australian sample, females reported higher scores on World of Work Knowledge and Career Decision Making subscales than males at all year levels.

In examining gender scores across the two countries, an interesting finding emerges. Australian females and males scored lower on career planning and career exploration than South African females and males in Year 9. On world of work and decision making knowledge, Australian males scored lower than South African males in Years 9, 10, and 12, and Australian females had higher scores than South African females in all years other than Year 9. These findings are supportive of a discussion of the inclusion of context in the analysis of career maturity. A possible explanation for this finding is that the time for making subject choices in South Africa is at Year 9. It can also be argued that at the South African school there is a systematic, sequential career education program implemented at all levels. This was not the case in the Australian school, where career education tends to occur at specific educational transition points. Perhaps the combination of the program and the intensity of subject selection prompt a more intensive focus on the part of the South African students.

This explanation does not account for the gender differences between countries on the two knowledge-based subscales. The higher scores for South African males over Australian males in Years 9, 10 and 12 may be accounted for by the more extensive career program they receive. However, this does not explain why the Australian females generally have higher knowledge-based scores than the South African sample as a whole and than Australian males. A possible explanation may be that there are less gender stereotypical expectations in Australia which prompts a greater proactivity in career knowledge search behaviour. Lokan (1984) also suggested that the higher scores on knowledge may be a reflection of gender differences in academic achievement recorded in secondary school. However, this explanation does not apply in South Africa, as the females scored lower than males on the two knowledge-based subscales. In addition, South African females in Year 9 had lower scores than their counterparts in Years 11 and 12 on knowledge subscales. Given that Year 9 is a specific decision point, such a finding is cause for concern, but may also reflect the 'distance' Year 9 is from the 'real' end of school career decision points. Such explanations need to be explored further. 
(C) 2004 Australian Council for Educational Research. This article may not exactly replicate the final version published in Australian Journal of Career Development. It is not a copy of the record. Final and authorised version first published in Australian Journal of Career Development in Vol 13, Issue 1, published by the Australian Council for Educational Research.

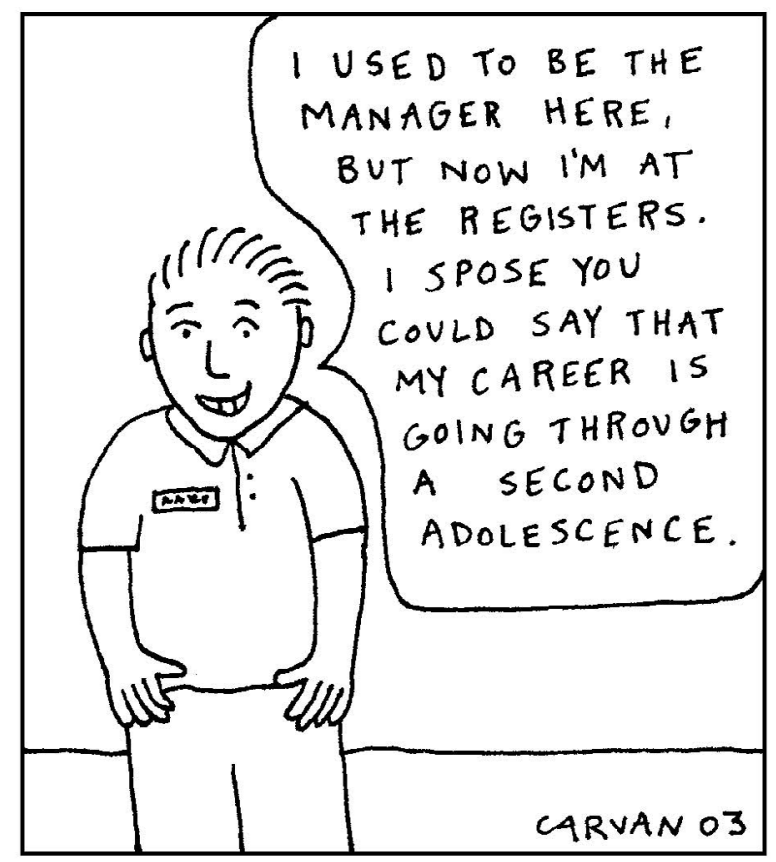

Overall, the grade level data are indicative of a developmental progression with lower year levels reporting lower scores on all four subscales. In the present study it is relevant to consider practical considerations such as planning activities conducted around school transition points. At Year 9 the activities conducted for these South African students as part of their program clearly are contributing to career maturity, as measured on all four subscales. Herr and Enderlein (1976) emphasised the relevance of school and curriculum in influencing the rate and level of career maturity. Timing of educational interventions and decisions are clearly relevant, therefore supporting the call for more attention to these factors in exploring career maturity (Vondracek \& Reitzle, 1998). In pursuing this discussion further, it is interesting that a similar finding did not occur for the equivalent timing point in Australia-Year 10. It is hard not to come to the conclusion that the career education activities undertaken to prepare Year 10 students for the important educational and career choices made at this time are inadequate, particularly when compared with the comprehensive program offered at the South African school.

In the present study, macro differences between countries appeared to have minimal effect on adolescent career maturity, therefore supporting the developmental explanation of career maturity. The existence of gender differences in both countries, and the difference in these effects, would suggest the need to further explore gender and cultural considerations in relation to career maturity development. It could also be argued that the young people in both countries have a similar educational experience and a similar perceived occupational opportunity and exposure to occupational alternatives. What is interesting is that these data suggest the relevance of school transition points in the development of adolescent career maturity. In addition, the data implies that differential preparation by the two schools for these transition points impacts on career maturity differentially. The contribution of the school curriculum to the career development of adolescents is crucial and schools need to pay more attention to career education offerings. Further research, using a pre-post data collection process with experimental 
(C) 2004 Australian Council for Educational Research. This article may not exactly replicate the final version published in Australian Journal of Career Development. It is not a copy of the record. Final and authorised version first published in Australian Journal of Career Development in Vol 13, Issue 1, published by the Australian Council for Educational Research.

and control groups, needs to be conducted to provide data on the relationship between career education and the development of career maturity.

\section{References}

Achebe, C. C. (1982). Assessing the vocational maturity of students in the East Central State of Nigeria. Journal of Vocational Behavior, 20, 153-61.

Akhurst, J., \& Mkhize, N. (1999). Career education in South Africa. In G. B. Stead \& M. B. Watson (Eds.), Career psychology in the South African context (pp. 163-79). Pretoria: J. L. van Schaik.

Alvi, S. A., \& Khan, S. B. (1983). An investigation into the construct validity of Crites' career maturity model. Journal of Vocational Behavior, 22, 174-181.

Crites, J. (1971). The maturity of vocational attitudes in adolescence. Washington, DC: APGA.

Crites, J. O. (1978). Theory and research handbook for the Career Maturity Inventory (2nd ed.) Monterey, CA: CTB/McGraw-Hill.

Fouad, N. A. (1988). The construct of career maturity in the United States and Israel. Journal of Vocational Behavior, 32, 49-59.

Gupta, N. (1987). Career maturity: A function of grade and sex. Indian Psychologist, 4, 19-31.

Herr, E. L., \& Enderlein, T. E. (1976). Vocational maturity: The effects of school, grade, curriculum and sex. Journal of Vocational Behavior, 8, 27-238.

Hickson, J., \& White, E. (1989). Career maturity development in black South African adolescents: Implications for vocational counselling. South African Journal of Education, 9, 77-81.

Jordaan, J. P., \& Heyde, M. B. (1979). Vocational maturity during the high school years. New York: Teachers College Press.

King, S. (1989). Sex differences in a causal model of career maturity. Journal of Counseling and Development, 68, 208-215.

Lokan, J. (1984). Manual of the Career Development Inventory- Australian Edition. Hawthorn, VIC: Australian Council for Educational Research.

Lokan, J. J., Boss, M. W., \& Patsula, P. J. (1982). A study of vocational maturity during adolescence and locus of control. Journal of Vocational Behavior, 20, 331-42.

Luzzo, D. A. (1995). The relationship between career aspiration-current occupation congruence and the career maturity of undergraduates. Journal of Employment Counseling, 32, 132-40.

Ministerial Council for Employment, Education, Training and Youth Affairs (MCEETA). (2000). Report. Canberra, ACT: Author.

Moracco, J. C. (1976). Vocational maturity of Arab and American high school students. Journal of Vocational Behavior, 8, 367-73.

Neice, D. E., \& Bradley, R. W. (1979). Relationship of age, sex and educational group to career decisiveness. Journal of Vocational Behavior, 14, 271-8.

Ohler, D., \& Levinson, E. (1994). Assessment of career maturity in transdisciplinary vocational assessment. (ERIC document, No ED 371 279).

Patton, W., \& Creed, P. (2001). Developmental issues in career maturity and decision making readiness. The Career Development Quarterly, 49, 336-51.

Patton, W., \& Lokan, J. (2001). Perspectives on Donald Super's construct of career maturity. International Journal of Educational and Vocational Guidance, 1, 31-48.

Pinkney, J. W., \& Bozik, C. M. (1994). Career Development Inventory: A review. In J. T. Kapes, M. M. Mastie, \& E. A Whitfield (Eds.). A counselor's guide to career assessment instruments (3rd Ed., pp. 263-7). Alexandria, VA: National Career Development Association.

Post-Kammer, P. (1987). Intrinsic and extrinsic work values and career maturity of 9th and 11th grade boys and girls. Journal of Counseling and Development, 65, 420-3. 
(C) 2004 Australian Council for Educational Research. This article may not exactly replicate the final version published in Australian Journal of Career Development. It is not a copy of the record. Final and authorised version first published in Australian Journal of Career Development in Vol 13, Issue 1, published by the Australian Council for Educational Research.

Powell, D. F., \& Luzzo, D. A. (1998). Evaluating factors associated with the career maturity of high school students. The Career Development Quarterly, 47, 145-1.

Raskin, P. (1998). Career maturity: The construct's validity, vitality, and viability. The Career Development Quarterly, 47, 32-5.

Reid-Van Niekerk, H. H., \& Van Niekerk, E. C. (1990). Career maturity of black, coloured and white university students. Journal of Industrial Psychology, 16, 1-4.

Savickas, M. L. (1984). Career maturity: The construct and its appraisal. Vocational Guidance Quarterly, 32, 222-31.

Savickas, M. L. (1994). Measuring career development: Current status and future directions. Career Development Quarterly, 43, 54-62.

Schmitt-Rodermund, E., \& Silbereisen, R. K. (1998). Career maturity determinants: Individual development, social context, and historical time. The Career Development Quarterly, 47, 16 31.

Statistics South Africa. (2000). Statistics in brief. Pretoria: Author.

Stead, G. B., \& Watson, M. B. (1998). The appropriateness of Super's career theory among black South Africans. South African Journal of Psychology, 28, 40-3.

Super, D. (1957). The psychology of careers. New York: Harper.

Super, D. (1990). A life span, life-space approach to career development. In D. Brown \& L. Brooks (Eds.), Career choice and development (2nd ed., pp. 197-261). San Francisco: JosseyBass.

Super, D. E., \& Nevill, D. D. (1984). Work role salience as a determinant of career maturity in high school students. Journal of Vocational Behavior, 25, 30-44.

Sweet, R. (1999). Youth: The rhetoric and the reality of the 90s. In Dusseldorp Skills Forum, Australia's Youth: From risk to opportunity. Sydney: Author.

Thompson, A. S., \& Lindeman, A. S. (1981). Career Development Inventory: Vol. 1, Users' Manual. Palo Alto, CA: Consulting Psychologists Press.

Vondracek, F. W., Lerner, R. M., \& Schulenberg, J. E. (1986). Career development: A life-span developmental approach. Hillsdale, NJ: Erlbaum.

Vondracek, F. W., \& Reitzle, M. (1998). The viability of career maturity: A developmentalcontextual perspective. The Career Development Quarterly, 47, 6-15.

Wallace-Broscious, A., Serafica, F. C., \& Osipow, S. H. (1994). Adolescent career development: Relationships to self-concept and identity status. Journal of Research on Adolescence, 4(1), $127-49$.

Watson, M. B., \& Van Aarde, J. A. (1986). Attitudinal career maturity of South African colored high school pupils. Journal of Vocational Behavior, 29, 7-16.

Watson, M. B., Stead, G. B., \& De Jager, A. C. (1995). The career development of black and white South African university students. International Journal for the Advancement of Counselling, 18, 39-47.

Westbrook, B. W. (1984). Career maturity: The concept, the instruments, and the research. In W. B. Walsh \& S. H. Osipow (Eds.), Handbook of vocational psychology (Vol. 1, pp. 263-303). Hillsdale, NJ: Erlbaum. 